\title{
A METHODOLOGY TO ADAPT PHOTOGRAMMETRIC MODELS TO VIRTUAL REALITY FOR OCULUS GEAR VR
}

\author{
A. Colmenero Fdez * \\ University of Vigo, PhD Candidate in Heritage Protection. Group Land Digitalization. Spain- mcolmenero@uvigo.es
}

KEY WORDS: Laser, photogrammetry, virtual reality, oculus, mobile, digital heritage.

\begin{abstract}
:
In this paper, we will expose the process of adapting a high resolution model (laser and photogrammetry) into a virtual reality application for mobile phones. It is a virtual archeology project carried out on the site of Lugo's Mitreo, Spain.
\end{abstract}

\section{INTRODUCTION}

One of the main components of a VR system is the threedimensional geometric representation within the reality engine. This reality engine needs a series of demanding requirements for the geometry in order to get the correct interaction through the device and the interface. The three-dimensional models have to comply not only with the Requirements Engineering (RE) which defines the behavior of a system, but also with the specifications of the design in which they are to be implemented. In addition, they have to meet the requirements of the creation of reusable repositories according to the standards (ISO / IEC 9126, SQuare ISO / IEC 25000), and follow principles of truthfulness as recommended by the London Charter and the Seville Principles.

When we are working with an extensive archaeological space to be visualized in virtual reality, the specifications of the weight of the geometric model influence the calculations of the virtual simulation in the frame buffer. In order to avoid latency problems that cause the effect known as virtual reality sickness, we have to keep in latency low, below 10 milliseconds.

We must also take into account that virtual reality scenery work with two cameras in order to recreate the effect of stereoscopy. Therefore the mobile device has to process the same object twice, duplicating the processing of both its mesh and its texture. The correct optimization of the model is one of the most important problems for correct virtual visualization.

In general, we need to comply with the following specifications:

- $\quad$ The scenery 3D models should not exceed 100 calls per frame.

- The total number of triangular geometry must be between $50 \mathrm{~K}$ and $100 \mathrm{~K}$ per frame.

- We must be careful with the size (more than $4 \mathrm{Kx} 4 \mathrm{~K}$ is not recommended) and number of textures.

Software solutions which automatically produce high resolution 3D models from photographs or laser-scans may present some problems in the processing of mesh reduction when we need a complex or extended model to have a maximum of $100 \mathrm{~K}$.
In this paper we present a methodology that allows us to obtain a digitized model adapted to be viewed in virtual reality with a minimal loss of geometric information.

\section{METHODOLOGY}

\subsection{THE ARCHAEOLOGICAL SPACE}

In 1998, the team of archaeologist D. Celso Rodríguez Cao excavated the "Pazo de Montenegro" of the University of Santiago de Compostela. It carried out an archaeological intervention in a space of more than 600 square meters in which a Roman domus of the High Imperial period (27 BC-284 AD) was found. It is made up of a ground floor with a paved patio, three rooms and an annex at the level of a second floor, which was identified as a mitrhaeum or mitreo. It was a place of worship dedicated to the god Mitra and this finding is one the most important of its kind in the Roman Empire. The archaeological site is currently musealized inside the "Casa do Saber".

This space presents a series of characteristics:

1. - It is located in a museum environment with numerous walkways and panels.

2.- The archaeological remains are distributed in two heights more than 4 meters underground in an inner zone flanked on one side by the wall of Lugo.

This presented a series of problems for the digitization with photogrammetry technique such as:

1. Difficulties to obtain the signal in the GPS device of the camera. This affects the actual scale of the final model.

In order to solve this problem with the scale, a mixed technique to unify photogrammetry and laser was used. The museum environment presented some problems in the dispersion of some points due to rebounds of the laser beam in the windows and reflections. 


\subsection{MATERIAL ELEMENTS}

$\begin{array}{ll}\text { - } & \text { Data capture: } \\ & \text { - Laser Faro Focus X-130 3D. } \\ & \text {-Nikon D3300, } 35 \mathrm{~mm} \text { lens, 24.2 MP resolution } \\ & \text { per image. } \\ & \text { 3D restitution software: } \\ & \text { - RealityCapture } \\ & \text { Processing equipment: } \\ & \text {-Intel core i5-7600 @ 3.5GHz, with 32GB of } \\ & \text { RAM. } \\ & \text { Optimization of the model. } \\ & \text { - Meshlab } \\ & \text {-Zbrush } \\ & \text { Bake map of normal and displacement } \\ & \text {-Xnormal } \\ & \text { Model Evaluation. } \\ & \text { - Cloudcompare } \\ & \text { Virtual reality } \\ & \text {-Unity }\end{array}$

Planning in the virtualization process for the Mitreo area:

- 7 laser scanning points.

- 1168 converging photographic images for isolated and parallel objects with lateral overlays for perimeter areas.

\subsection{PROCESSING THE IMAGES.}

Five archaeological spaces have been digitized. We now proceed to explain the digitization of one of them, Mitreo's area.

For the digitization of this area a mixed technique has been used following by processing with the software of Reality Capture.

The final virtual model has $569.8 \mathrm{M}$ tris that has been automatically optimized to $10.2 \mathrm{M}$ triangles, with a maximum error of $5 \mathrm{~mm}$ accuracy.

Automatic minimization of polygons supported by the VR device may present problems such as open mesh and undefined areas.

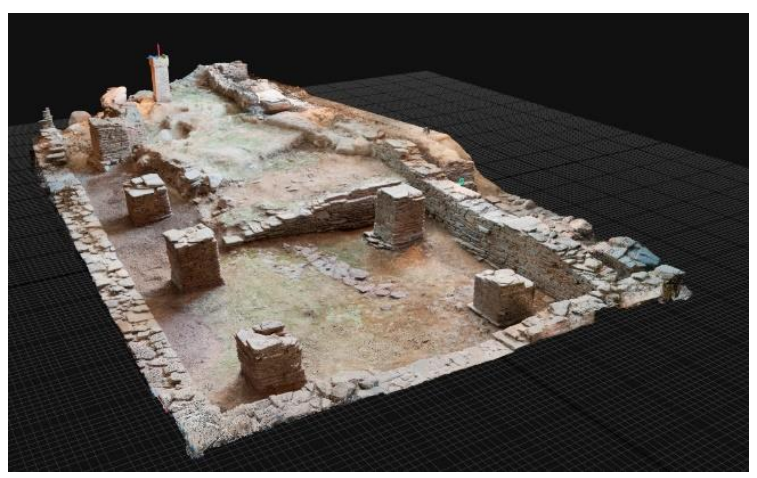

Figure 1. Optimized Model. 10.2 M triqs

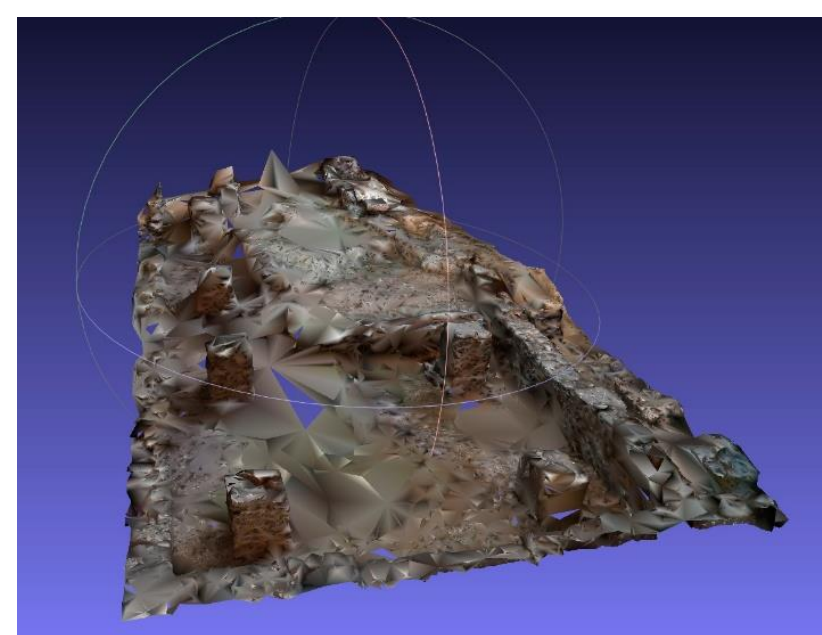

Figure 2. Model automatically reduce in Reality Capture to 10k.

\subsection{PROCESSING AND OPTIMIZATED MODELS}

After optimizing the cloud of points and cleaning up those unnecessary sectors, we proceeded to optimize the model in parts.

For this the following independent models are generated:

The Ara Votive (which we are going to present as an example of the rest of the procedures)

- The 6 pilasters

- Interior and exterior wall.

-Soil.

For each independent object a maximum of $4.6 \mathrm{k}$ per model has been estimated.

The retopolization phase consists in converting a high resolution model to a low poly model which maintains the details through the bake of normal maps and displacement. There is also an orderly redistribution of the mesh that allows us to work and to correct more easily with the possible problems of the textured process. 


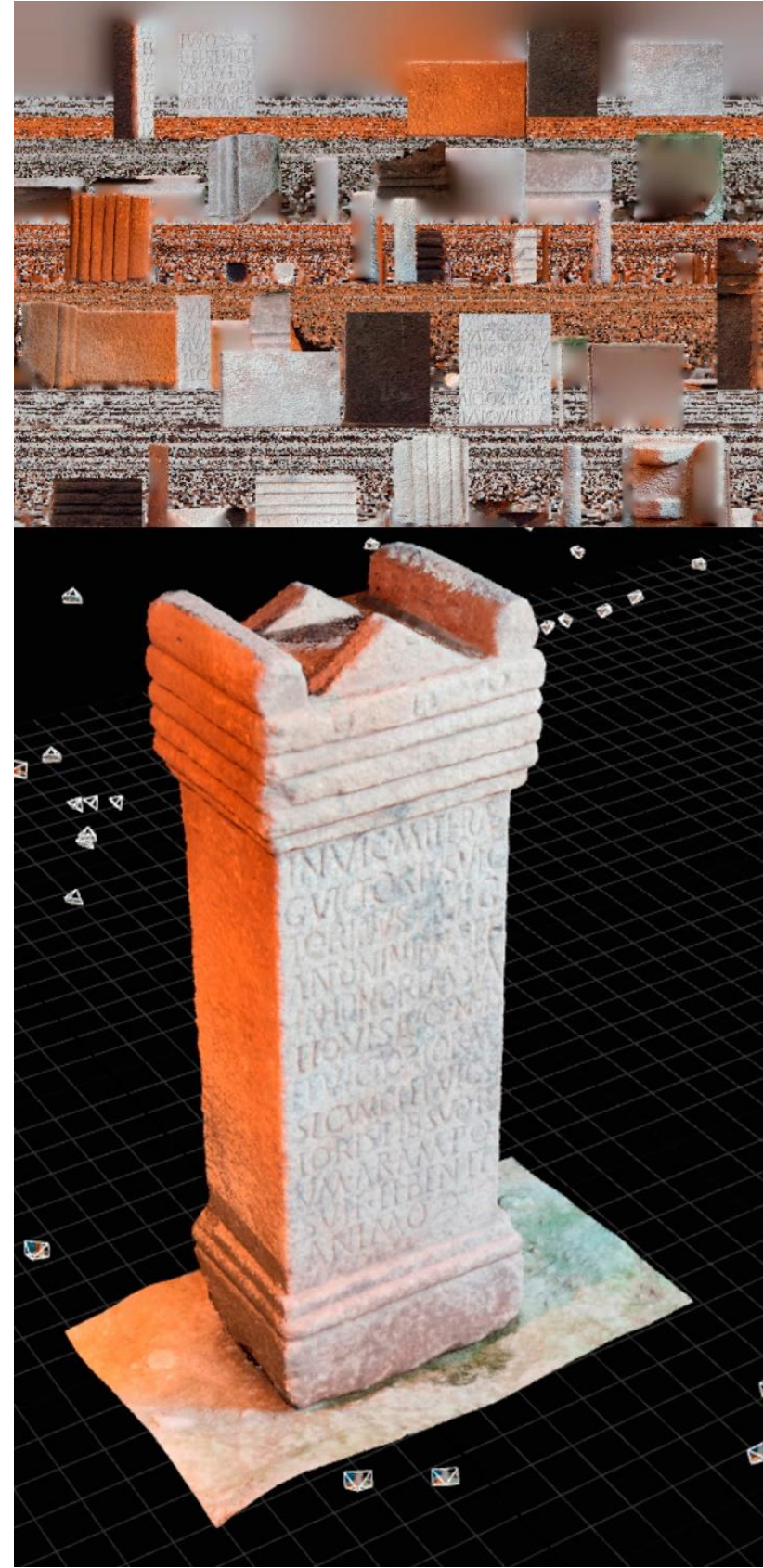

Figure 3. Texturing and high resolution model. Ara votive 12M triqs
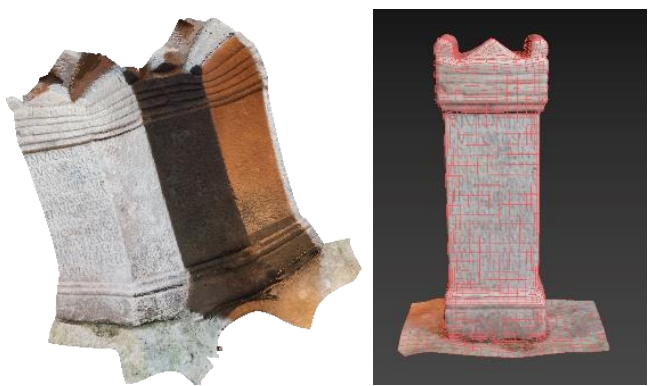

Figure 4. Texturizado y modelo en baja resolución. Ara votiva en $4 \mathrm{k}$.

\section{RESULTS}

There are some methods for make the retopology, manually and automatically. We will outline a method for carrying out a fast retopology using zbrush.

Zbrush has a tool, zremesh, that allows us to do a re-polishing of the mesh controlling the number of final polygons and the unwrapping of the textured area. This final model can be subdivided and projected to the original model to obtain best results.

In the comparison of two models, the best results are for the retopoligy with zbrush.
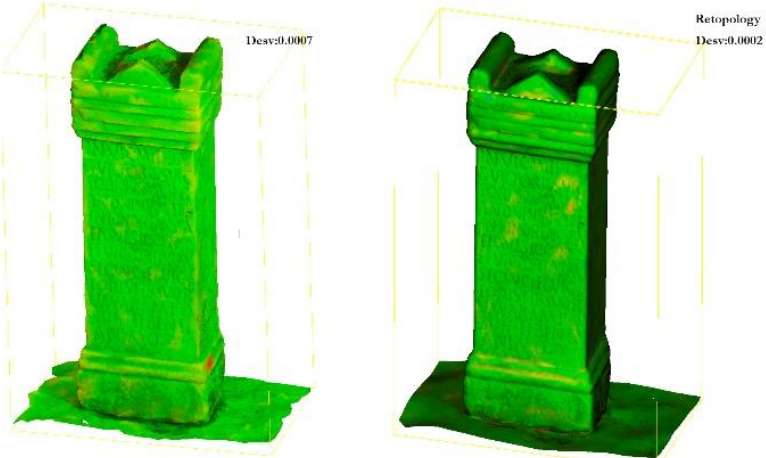

Figure 5. Model 4k from Capture Reality on left and model retopology on right.

\section{REFERENCES}

AA. VV., 2011. A domus do mitreo, pp. 112-117. Universidad Santiago de Compostela.

Alarcao Alegre, E., 2004. Realidad virtual y Reconstrucción 3d: ¿Arqueología o Ciencia Ficción?. Actas del I Encuentro Internacional , 5-7 mayo, 2003. Universidad de Córdoba.

Charquero Ballester, Ana $\mathrm{M}^{\mathrm{a}}$., 2016. Práctica y usos de la fotogrametría digital en arqueología. Dama 1. Documentos de Arqueología y Patrimonio Histórico. Universidad de Alicante.

Colmenero, Fernández Alicia., 2012. Anastilosis Virtual de: A Domus do Mitreo de Lvcvs Avgvsti. Virtual Archaeology review.

Carrillo Gea, J.M., 2013. The London Charter and the Sevilla Principles as sources of requeriments for e-archaeology, system development purpose. Virtual Archaeology review, 4(9),205211. http://doi.org/10.4995/var.2013.4275

Carrozzino, M., 2010. Beyond virtual museums: Experiencing immersive virtual reality in real museums, Journal of cultural Heritage, 11, 452-458.

Lerma, J. L., 2002. Fotogametría Moderna: Analítica y digital. Editorial Universidad Politécnica de Valencia. 